\title{
Multiple Bovine Papillomavirus Infections Associated with Cutaneous Papillomatosis in Brazilian Cattle Herds
}

\author{
Marlise Pompeo Claus ${ }^{1}$, Michele Lunardi ${ }^{1}$, Amauri Alcindo Alfieri ${ }^{1}$, Rodrigo Alejandro \\ Arellano Otonel ${ }^{1}$, Daniele Sartori ${ }^{2}$, Maria Helena Pelegrinelli Fungaro ${ }^{2}$ and Alice \\ Fernandes Alfieri ${ }^{1 *}$ \\ ${ }^{1}$ Laboratório de Virologia Animal; Departamento de Medicina Veterinária Preventiva; Universidade Estadual de \\ Londrina; Londrina - PR - Brasil. ${ }^{2}$ Faculdade de Biologia; Universidade Estadual de Londrina; Londrina - PR - \\ Brasil
}

\begin{abstract}
Cutaneous papillomatosis is a pathological condition commonly found in cattle and is characterized by the presence of benign proliferative tumors caused by bovine papillomavirus (BPV) infection. While multiple infections with human papillomavirus (HPV) are common in healthy and immunodeficient humans, studies with the aim of identifying mixed infections are still sporadic in veterinary medicine. The aim of this study is to describe the occurrence of multiple BPV infections in cattle affected by cutaneous papillomatosis. Fifteen skin warts were collected from at least two diverse anatomical regions of six bovines with papillomatosis belonging to three cattle herds from the Paraná state in Brazil. The BPV types present in the skin wart samples were determined by a PCR assay performed with the FAP primer pair for partial L1 gene amplification followed by direct sequencing or by cloning and sequencing of the inserts. Sequence analysis of the obtained amplicons allowed the identification of four characterized BPV types (BPV-1, -2, -6, and -8) and three previously described putative new BPV types (BPV/BRUEL3, BPV/BR-UEL4, and BPV/BR-UEL5). Double infections were identified in four $(A, B, D$, and E) of the six animals included in this study. In this work, the strategy adopted to evaluate skin warts from diverse anatomical sites of the same animal allowed the identification of multiple infections with two or three different BPV types. The analysis of four animals belonging to a single cattle herd also showed the presence of six different viral types. These results clearly suggest that both multiple papillomaviral infection and a high viral diversity can be as frequent in cattle as in human beings.
\end{abstract}

Key words: cattle, skin warts, BPV, mixed infections

\section{INTRODUCTION}

Papillomatosis is a benign proliferative tumor of cutaneous and mucosal epithelia that is commonly found in cattle. The disease affects mainly young animals up to two years of age; however, cattle of all ages can develop such lesions (Campo and Jarret, 1994; Jelínek and Tachezy, 2005).

While hundreds of papillomavirus (PV) types have been described in humans, only ten bovine papillomavirus (BPV) types (BPV-1 to -10) are recognized (de Villiers et al., 2004; Ogawa et al.,

*Author for correspondence: alfieri@uel.br 
2007; Tomita et al., 2007; Hatama et al., 2008). Nevertheless, through the use of PCR with general primers for L1 followed by direct sequencing of the amplicons, sixteen putative new BPV types were described in cattle from Sweden, Japan, and Brazil in the last few years (Antonsson and Hansson, 2002; Ogawa et al., 2004; Claus et al., 2008).

In Brazil, despite the high frequency of skin warts in bovines, studies involving both BPV genotyping and the evaluation of BPV infection prevalence are uncommon. In addition, most studies that aim for viral genotyping have been based on a PCR assay with type-specific primers (Santos et al., 1998; Wosiacki et al., 2005; 2006). However, recent investigations employing the degenerate FAP primers have demonstrated the occurrence of considerable viral diversity in BPV infections throughout Brazilian cattle herds (Claus et al., 2007; 2008; 2009a/b).

Despite the frequent description of multiple human papillomavirus (HPV) infections in humans, studies involving the evaluation of the occurrence of mixed BPV infections are still sporadic in veterinary medicine. The aim of this study is to describe the occurrence of multiple BPV infections in cattle affected by cutaneous papillomatosis.

\section{MATERIALS AND METHODS}

\section{Papilloma specimens}

Fifteen papilloma specimens were collected from at least two different body sites of six bovines with cutaneous papillomatosis belonging to three cattle herds from northern region of Parana state in southern Brazil. The clinical specimens were taken by hand (wearing gloves, changed for each sample), packed individually, and maintained at $4^{\circ} \mathrm{C}$ until the DNA extraction procedure was completed. Fragments from each skin wart were triturated in phosphate-buffered saline solution (PBS pH 7.2), and the suspensions (10-20\%, w/v) were centrifuged for $15 \mathrm{~min}$ at $3000 \mathrm{x} g$ at $4^{\circ} \mathrm{C}$. Aliquots $(250 \mu \mathrm{L})$ of the supernatant were treated with lysis buffer $[10 \mathrm{mM}$ Tris; $1 \mathrm{mM}$ EDTA; $0.5 \%$ Nonidet P40; $1 \%$ SDS; and $0.2 \mathrm{mg} / \mathrm{mL}$ proteinase $\mathrm{K}$ (Invitrogen, Life Technologies, USA)]. After homogenization, the samples were incubated at $56^{\circ} \mathrm{C}$ for $30 \mathrm{~min}$.

\section{DNA extraction}

For DNA extraction, a combination of the phenol/chloroform/isoamyl alcohol and the silica/guanidine isothiocyanate methods was performed according to Alfieri et al. (2006). Briefly, fractions from each sample were treated with an equal volume of phenol/chloroform/isoamyl alcohol (25:24:1), homogenized, and heated at $56^{\circ} \mathrm{C}$ for $15 \mathrm{~min}$ (Sambrook and Russell, 2001). After centrifugation at $10,000 \times \mathrm{g}$ for $10 \mathrm{~min}$, the aqueous phase was processed according to the silica/guanidine isothiocyanate method (Boom et al., 1990). DNA was eluted in $50 \mu \mathrm{L}$ of sterile ultrapure $\left(\mathrm{MilliQ}^{\circledR}\right)$ water and kept at $-20^{\circ} \mathrm{C}$ until use. Aliquots of sterile ultrapure water were included as negative control in the DNA extraction procedures.

\section{PCR assay}

The PCR assay was carried out using the primer pair FAP59 (forward; 5'TAACWGTIGGICAYCCWTATT-3') and FAP64 (reverse; 5'CCWATATCWVHCATITCICCATC-3')

according to Forslund et al. (1999), with slight modifications (Claus et al., 2007). A $5 \mu \mathrm{L}$ aliquot of each PCR products was analyzed by electrophoresis on a $2 \%$ agarose gel in TBE buffer, pH 8.4 ( $89 \mathrm{mM}$ Tris; $89 \mathrm{mM}$ boric acid; $2 \mathrm{mM}$ EDTA) at a constant voltage (90V) for approximately $45 \mathrm{~min}$. The gel was stained with ethidium bromide $(0.5 \mu \mathrm{g} / \mathrm{mL})$ and visualized under UV light.

\section{Sequence analysis}

Initially, all PCR products were purified using the PureLink Quick Gel Extraction Kit (Invitrogen, Life Technologies, USA). After purification, direct sequencing was performed using the DYEnamic ET dye terminator cycle sequencing kit (GE Healthcare, UK) with the FAP59 and FAP64 primers in a MegaBACE 1000/Automated 96 Capillary DNA Sequencer (GE Healthcare, UK), according to the manufacturer's instructions.

The obtained sequences were examined with PHRED software for quality analysis of the chromatogram readings. The sequences were accepted if the base quality was equal to or greater than 20. Consensus sequences were determined by CAP3 software and the sequence identity was verified with all sequences deposited in GenBank using BLAST software. 


\section{Cloning}

For the amplicons that were revealed as putative new BPV types by the prior analysis (Claus et al., 2008), cloning using the TOPO TA Cloning kit for Sequencing (Invitrogen, Life Technologies, USA) was carried out according to the manufacturer's instructions. Sequencing in both directions, using M13 forward and reverse primers, of plasmid DNA from two selected clones of each PVpositive sample was performed. The alignment and the degree of similarity among the sequences were obtained using BioEdit version 5.0.9 software (Hall, 1999).

\section{RESULTS AND DISCUSSION}

PV DNA was detected in all 15 papilloma specimens evaluated using the FAP PCR assay, resulting in amplicons of approximately $480 \mathrm{bp}$ in length. The negative control for PCR amplification resulted in no amplified product. Sequence analysis of the obtained amplicons allowed the identification of four characterized BPV types (BPV-1, -2, -6, and -8) and of three previously described putative new BPV types (BPV/BRUEL3, BPV/BR-UEL4, and BPV/BR-UEL5) in different mixed infection patterns (table 1). The skin warts in which the putative new BPV types were detected were the same samples employed by Claus et al (2008) in the description of these viruses in Brazilian cattle herds.

Double infections were identified in four (A, B, D, and $\mathrm{E}$ ) of the six animals included in this study. In animal F, from which three skin warts were analyzed, two different BPV types could be detected. Regarding animal $\mathrm{C}$, in which four different cutaneous lesions were taken, three BPV types were identified. In animals $\mathrm{C}, \mathrm{D}$, and $\mathrm{F}$, at least one of the identified BPV types was a putative new BPV type described by Claus et al. (2008). Therefore, we could identify five different combinations of multiple infections occurring in six animals. This result clearly shows the multiplicity of the BPV infections in the animals and the herds evaluated.

The cattle herds included in this evaluation were from distinct geographical regions of the Paraná state, each separated by a distance of approximately 200 kilometers. Moreover, the papilloma specimens were collected over a period of two years. Given the geographical and temporal characteristics of our sampling, it is probable that the cases described in this study did not represent sporadic outbreaks of cutaneous papillomatosis. Instead, these findings suggest that the occurrence of multiple BPV infection may be widespread throughout cattle herds from the Paraná state in Brazil. Since the cutaneous papillomatosis verified in different Brazilian cattle herds displays similar clinical profiles, it is likely that multiple infections may occur in other Brazilian geographical regions. Although the BPV-6 has been frequently associated with papillomas from the teat, in this study we found this BPV type in cutaneous lesions with different macroscopic aspects in distinct anatomical sites (table 1).

Table 1 - Distribution of bovine papillomavirus types found in multiple infections.

\begin{tabular}{|c|c|c|c|c|}
\hline \multirow{2}{*}{ Herd } & \multirow{2}{*}{ Animal } & \multicolumn{2}{|c|}{ Papilloma specimen / character } & \multirow{2}{*}{ BPV type } \\
\hline & & Gross aspect & Location & \\
\hline \multirow{2}{*}{1} & \multirow{2}{*}{$\mathrm{A}^{1}$} & rice-grain & crest & 1 \\
\hline & & rice-grain & teat & 6 \\
\hline \multirow{2}{*}{1} & \multirow{2}{*}{$\mathrm{B}^{2}$} & flat and round & dorsal thorax & 1 \\
\hline & & flat and round & scapula & 2 \\
\hline \multirow{4}{*}{1} & \multirow{4}{*}{$\mathrm{C}^{1}$} & rice-grain & chest & 6 \\
\hline & & rice-grain & teat & 8 \\
\hline & & flat and round & scapula & 8 \\
\hline & & flat and round & dorsal thorax & BPV/BR-UEL3* \\
\hline \multirow{2}{*}{1} & \multirow{2}{*}{$\mathrm{D}^{2}$} & cauliflower & back & 6 \\
\hline & & cauliflower & teat & BPV/BR-UEL5 ${ }^{*}$ \\
\hline \multirow{2}{*}{2} & \multirow{2}{*}{$\mathrm{E}^{2}$} & cauliflower & neck & 1 \\
\hline & & cauliflower & scapula & 2 \\
\hline \multirow{3}{*}{3} & \multirow{3}{*}{$\mathrm{F}^{1}$} & rice-grain & neck & 2 \\
\hline & & cauliflower & dorsal thorax & 2 \\
\hline & & frond & tailhead & BPV/BR-UEL4* \\
\hline
\end{tabular}


Currently the use of PCR assay with general primers for the L1 gene, followed by sequencing, has allowed the immediate identification of PV types and putative new PV types in human and animal hosts. This strategy has also allowed the identification of multiple infections and coinfection by distinct PV types in the same host (Forslund et al., 1999; Antonsson and Hansson, 2002; Ogawa et al., 2004; Maeda et al., 2007).

Investigations in human beings have pointed to the occurrence of HPV mixed infection in different tumors collected from the same patient (Astori et al., 1997; Bens et al., 1998; Kay et al., 2002). On the other hand, studies with the aim of identifying BPV types associated with different skin warts from individual animals have not been performed. In the current study, the strategy adopted to evaluate cutaneous lesions of diverse anatomical regions of the same animal, allowed the identification of mixed infections with two or three different BPV types. Additionally, the analysis of four animals belonging to a single cattle herd revealed the presence of six different viral types. These results suggest that both multiple papillomaviral infections and high viral diversity can be as frequent in cattle as in human hosts.

In addition, as demonstrated in table 1 , the following findings could be verified: i) the occurrence of several BPV types in a specific anatomical region; ii) the detection of the same viral type in distinct body sites; iii) a specific BPV type determining cutaneous lesions with diverse gross aspects; and iv) diverse viral types being able to cause skin lesions with similar morphological characteristics.

Although benign lesions normally regress spontaneously, the persistence of skin warts has been seen in a large number of animals. According to our findings, this observation could be explained by the occurrence of multiple infections without cross-reactive immunity.

The identification of multiple BPV infections may contribute to the understanding of the epidemiological, clinical, and immunological features of cutaneous papillomatosis in cattle. Furthermore, our findings point to the importance of in-depth and regional studies aiming to verify the most prevalent BPV types in skin warts and demonstrate that future vaccine design should consider the multiple character of BPV infections.

\section{ACKNOWLEDGEMENTS}

The financial resources for the conduction of this study were supported by the project BioAgroPar financed by FINEP, SETI/PR, and Fundação Araucária/PR; and by $\mathrm{CNPq} / \mathrm{MAPA} / \mathrm{SDA}$ (064/2008).

Part of the research activities of this study was carried out in the Agricultural Research Support Laboratory (Laboratório de Apoio à Pesquisa Agropecuária - LAPA) / PROPPG / UEL.

Alfieri, Alfieri, and Fungaro are recipients of CNPq fellowships.

\section{RESUMO}

A papilomatose cutânea é comumente observada nos rebanhos bovinos e caracterizada pela presença de tumores proliferativos benignos causados pela infecção pelo papilomavírus bovino (BPV). Enquanto a infecção múltipla pelo papilomavírus humano (HPV) é um achado comum tanto em seres humanos saudáveis quanto em pacientes com imunodeficiência, na medicina veterinária esses relatos ainda são escassos. O objetivo desse estudo foi descrever a ocorrência de infecções múltiplas pelo BPV em rebanhos afetados pela papilomatose cutânea. Quinze papilomas foram obtidos, de pelo menos duas regiões anatômicas diferentes, de seis bovinos com papilomatose e provenientes de três rebanhos de corte localizados no estado do Paraná, Brasil. Os tipos virais presentes nas lesões foram identificados por PCR, utilizando o par de oligonucleotídeos iniciadores FAP, seguidos de sequenciamento direto ou clonagem e novo sequenciamento dos insertos. A análise das sequências obtidas permitiu a identificação do BPV-1, -2, -6 e -8, além de supostos novos tipos (BPV/BR-UEL3, BPV/BR-UEL4, e BPV/BRUEL5), descritos anteriormente. Infecções por dois tipos diferentes de BPV foram identificadas em quatro animais (A, B, D e E) dos seis incluídos nesse estudo. A estratégia adotada neste estudo permitiu a identificação de infecção múltipla por dois ou três diferentes tipos virais do BPV no mesmo animal. Além disso, a avaliação de quatro animais de um mesmo rebanho demonstrou a presença de seis tipos virais circulantes. Esses 
resultados sugerem que tanto as infecções múltiplas quanto a grande diversidade viral podem ser frequentes nos bovinos, assim como o observado nos humanos. O reconhecimento da multiplicidade e complexidade das infecções pelo BPV pode colaborar para o entendimento dos aspectos epidemiológicos, clínicos e imunológicos da papilomatose cutânea nos rebanhos bovinos.

\section{REFERENCES}

Alfieri, A. A., Parazzi, M. E., Takiuchi, E., Médici, K. C., Alfieri, A. F. (2006), Frequency of group A rotavirus in diarrhoeic calves in Brazilian cattle herds, 1998-2002. Trop Anim Health Prod, 38, 521-526

Antonsson, A., Hansson, B. G. (2002), Healthy skin of many species harbors papillomaviruses which are closely related to their human counterparts. $J$ Virol, 76, 2537-2542

Astori, G., Arzese, A., Pipan, C., de Villiers, E-M., Botta, G. A. (1997), Characterization of a putative new HPV genomic sequence from a cervical lesion using L1 consensus primers and restriction fragment length polymorphism. Virus Res, 50, 57-63

Bens, G., Wieland, U., Hofmann, A., Höpfl, R., Pfister, H. (1998), Detection of new human papillomavirus sequences in skin lesions of a renal transplant recipient and characterization of one complete genome related to epidermodysplasia verruciformisassociated types. J Gen Virol, 79, 779-787

Boom, R., Sol, C. J. A., Salimans, M. M. M., Jansen, C. L., Wertheim-Van Dillen, P. M. E., Noordaa, J. Van Der. (1990), Rapid and simple method for purification of nucleic acids. J Clin Microbiol, 28, 495-503

Campo, M. S., Jarret, W. F. (1994), Vaccination against cutaneous and mucosal papillomavirus in cattle. Ciba Found Symp, 187, 61-73

Claus, M. P., Vivian, D., Lunardi, M., Alfieri, A. F., Alfieri, A. A. (2007), Phylogenetic analysis of bovine papillomavirus associated with skin warts in cattle herds from the state of Parana. Pesq Vet Bras, 27, 314-318
Claus, M. P, Lunardi, M., Alfieri, A. F., Ferracin, L. M., Fungaro, M. H. P., Alfieri, A. A. (2008), Identification of unreported putative new bovine papillomavirus types in Brazilian cattle herds. Vet Microbiol, 132, 396-401

Claus, M. P, Lunardi, M., Alfieri, A. F., Sartori, D., Fungaro, M. H. P., Alfieri, A. A. (2009a), Identification of the recently described new type of bovine papillomavirus (BPV-8) in Brazilian beef cattle herd. Pesq Vet Bras, 29, 25-28

Claus, M. P, Lunardi, M., Alfieri, A. A., Otonel, R. A. A., Ferracin, L., Fungaro, M. H. P., Alfieri, A. F. (2009b), A Bovine Teat Papilloma Specimen Harboring Deltapapillomavirus (BPV-1) and Xipapillomavirus (BPV-6) Representatives. Braz, Arch Biol Technol, 52, 87-91

Villiers, E-M., Fauquet, C., Broker, T. R., Bernard, H. U., zur Hausen, H. (2004), Classification of papillomaviruses. Virol, 324, 17-27

Forslund, O., Antonsson, A., Nordin, P., Hansson, B. G. (1999), A broad range of human papillomavirus types detected with a general PCR method suitable for analysis of cutaneous tumours and normal skin. J Gen Virol, 80, 2437-2443

Hall, T. A. (1999), BioEdit: a user-friendly biological sequence alignment editor and analysis program for Windows 95/98/NT. Nucleic Acids Symp, 41, 95-98

Hatama, S., Nobumoto, K., Kanno, T. (2008), Genomic and phylogenetic analysis of two novel bovine papillomaviruses, BPV-9 and BPV-10. J Gen Virol, 89, 158-163.

Jelínek, F., Tachezy, R. (2005), Cutaneous papillomatosis in cattle. J Comp Pathol, 132, 70-81

Kay, P., Meehan, K., Williamson, A-L. (2002), The use of nested polymerase chain reaction and restriction fragment length polymorphism for the detection and typing of mucosal human papillomaviruses in samples containg low copy numbers of viral DNA. $J$ Virol Meth, 105, 159-170

Maeda, Y., Shibahara, T., Wada, Y., Kadota, K., Kanno, T., Uchida, I., Hatama, S. (2007), An outbreak of teat papillomatosis in cattle caused by bovine papilloma virus (BPV) type 6 and unclassified BPVs. Vet Microbiol, 121, 242-248 
Ogawa, T., Tomita, Y., Okada, M., Shinozaki, H. K., Kaiho, I., Shirasawa, H. (2004), Broad-spectrum detection of papillomaviruses in bovine teat papillomas and health teat skin. J Gen Virol, 85, 2191-2197

Ogawa, T., Tomita, Y., Okada, M., Shirasawa, H. (2007), Complete genome and phylogenetic position of bovine papillomavirus type 7. J Gen Virol, 88, 1934-1938

Sambrook, J., Russell, D. W. (2001), Molecular Cloning: A Laboratory Manual. Cold Spring Harbor Laboratory, New York

Santos, R. C. S., Lindsey, C. J., Ferraz, O. P., Pinto, J. R., Mirandola, R. S., Benesi, F. J., Birgel, E. H., Pereira, C. A. B., Beçak, W. (1998), Bovine papillomavirus transmission and chromosomal aberrations: an experimental model. J Gen Virol, 79, 2127-2135
Tomita, Y., Literák, I., Ogawa, T., Jin, Z., Shirasawa, H. (2007), Complete genomes and phylogenetic positions of bovine papillomavirus type 8 and a variant type from a European bison. Virus Genes, 35, 243-249

Wosiacki, S. R., Barreiros, M. A. B., Alfieri, A. F., Alfieri, A. A. (2005), Semi-Nested-PCR for detection and typing of bovine papillomavirus type 2 in urinary bladder and whole blood from cattle with enzootic haematuria. J Virol Meth, 126, 215-219

Wosiacki, S. R., Claus, M. C., Alfieri, A. F., Alfieri, A. A. (2006), Bovine papillomavirus type 2 detection in the urinary bladder of cattle with chronic enzootic haematuria. Mem Inst Oswaldo Cruz, 101, 635-638 